\title{
AOR
}

Selected Papers of \#AoIR2018:

The $19^{\text {th }}$ Annual Conference of the

Association of Internet Researchers

Montréal, Canada / 10-13 October 2018

\section{WHO PUT THE 'SOCIAL' IN MOBILE AND SOCIAL PAYMENT PLATFORMS? RE-READING SIMMEL AND COLLEAGUES IN LIGHT OF THE CAMBRIAN EXPLOSION}

\author{
Martin Johannes Riedl \\ The University of Texas at Austin
}

This research considers the Cambrian explosion (Nelms, Maurer, Swartz, \& Mainwaring, 2017) of mobile and social payment technologies from a perspective that integrates classical theorizing on money and payments (Mauss, 2002; Simmel, 2005), more recent work (Bandelj, Wherry, \& Zelizer, 2017; Dodd, 2014; Maurer, 2015; Zelizer, 2017), as well as research coming out of the Future of Money Research Collaborative and MoneyLab at the Institute of Network Cultures at Amsterdam. The paper negotiates mobile and social payment apps and the social realities that they stand upon and applies theoretical viewpoints from key authors to the emerging technologies. Based on a contemporary investigation of what 'social' entails in payment spaces, the paper then analyzes, via the walkthrough method (Light, Burgess, \& Duguay, 2016) and a content analysis of app store material, the social nature of a selection of payment platforms.

\section{Payment Penetration}

A Cambrian explosion (Nelms et al., 2017), as some have called the influx in new payment technologies over the last few years, has penetrated people's smartphones and social lives through platforms such as Zelle, Apple Pay Cash, Square Cash, Google Pay, WeChat Pay, Alipay, and Venmo. Some of these payment technologies are described as 'socializing' (Kremers \& Brassett, 2017), because they add social media to previously dry matter (Venmo), submerge payments into social media/operating systems (WeChat Pay), integrate themselves into messaging services (Apple Pay Cash), and/or replace physical wallets altogether (Square Cash, Google Wallet).

Suggested Citation (APA): Riedl, M.J. (2018, October 10-13). Who put the 'social' in social payment platforms? Re-reading Simmel and colleagues in light of the Cambrian explosion. Paper presented at AolR 2018: The $19^{\text {th }}$ Annual Conference of the Association of Internet Researchers. Montréal, Canada: AolR. Retrieved from http://spir.aoir.org. 


\section{The Socialness of 'Just Us'}

At their core, mobile and social payment systems can be considered social because of "their intimate connection to users' private lives" (Kremers \& Brassett, 2017, p. 10), or through the notion of "just us" (Nelms et al., 2017, p. 12), an ideal-typical social enactment of payment, void of government, corporate, and other influences. If "surveillance capitalism" (Zuboff, 2015) is about the monetization of data, we can think of this as the datafication of money, wherein the social permeates payment apps and datafies financial transactions. Trust, a central concern in all money matters, becomes visible through app transactions.

\section{(In)visibility and Public Databasing}

Social aspects of payment processes are made visible (and in some cases public), while the visibility of money remains behind a veil. Behind the scenes, the larger trend of creating public databases of transactions has gained popularity and possibility through blockchain technologies. Some payment apps such as Venmo provide public feeds of the messages that accompany payments.

\section{Simmel's Struggles With Money}

Mobile and social payment apps represent a formidable counter-thesis to Georg Simmel's money skepticism. Simmel has described money as a "claim upon society" (Simmel, 2005, p. 176), that results in a "sense in which money's value ... rests on social relations between its users that are fluid and dynamic" (Dodd, 2015, p. 438). According to Simmel, money is completely objective, a matter of quantity and not quality. Money is "the absolute freedom from everything personal" (Simmel, 2005, p. 126). Simmel's utilitarian perspective assumes money is a mode of objectifying people (Coeckelbergh, 2017).

\section{Maussian Gifting}

In The Gift (2002), Marcel Mauss proposed that there is no such thing as a true gift, because gifting leads to reciprocity. According to Simmel "a gift in the form of money distances and estranges the gift from the giver" (2005, p. 335). In mobile and social payment apps, gifting plays an important role - e.g., in red packet gifting through WeChat Pay during the Chinese New Year (Wu \& Ma, 2017) or cash-wrapping functions in Square Cash (Barbosa, 2016) - and this gifting function upends Simmel's conception.

\section{Back to the Social}

It is the reintroduction of the social into monies, what Zelizer (2017) refers to as earmarking, or setting aside money for specific (social) purposes, that updates Simmel's work to fit mobile and social payments. According to Perry and Ferreira (2018), Zelizer's understanding of money has contributed to an extraeconomic, social perspective, and Bandelj et al. (2017) diagnose a "historical paradox" (p. 4), in which classical sociology has been turned upside down by contemporary research that emphasizes the 
socialness of money, such as Dodd (2015), who holds that money is " process, not a thing"

\section{Preliminary Analysis}

The empirical core of this work-in-progress employs the walkthrough method (Light et al., 2016), and compares select mobile and social payment apps. Furthermore, the researcher content-analyzes app store screenshots, as well as descriptions, and sampled reader reviews in app stores. Preliminary analysis attempts to map apps on a continuum of sociality/publicness, with Venmo and its social feed on the liberal side of the spectrum. Criteria for analysis follow conceptual categories from scholarship outlined above, such as visibility, objectivity, freedom from everything personal, gifting, and earmarking capacities.

\section{References}

Bandelj, N., Wherry, F. F., \& Zelizer, V. A. (Eds.). (2017). Money talks: Explaining how money really works. Princeton University Press.

Barbosa, G. (2016, September 13). Square Cash update includes promised Messages app plus Siri integration. 9to5Mac. Retrieved from https://9to5mac.com/2016/09/13/square-cash-messages-app-siri/

Coeckelbergh, M. (2017). Quantification machines and artificial agents in global finance: Historical-phenomenological perspectives from philosophy and sociology of technology and money. In E. Ippoliti \& P. Chen (Eds.), Methods and finance: $A$ unifying view on finance, mathematics and philosophy (pp. 169-178). Springer.

Dodd, N. (2014). The social life of money. Princeton and Oxford: Princeton University Press.

Dodd, N. (2015). Redeeming Simmel's money. HAU: Journal of Ethnographic Theory, 5(2), 435-441.

Kremers, R., \& Brassett, J. (2017). Mobile payments, social money: Everyday politics of the consumer subject. New Political Economy, 22(6), 645-660. http://doi.org/10.1080/13563467.2017.1306503

Light, B., Burgess, J., \& Duguay, S. (2016). The walkthrough method: An approach to the study of apps. New Media \& Society. http://doi.org/10.1177/1461444816675438

Maurer, B. (2015). How would you like to pay? How technology is changing the future of money. Durham and London: Duke University Press.

Mauss, M. (2002). The gift: The form and reason for exchange in archaic societies. London and New York: Routledge. http://doi.org/10.4324/9781912281008

Nelms, T. C., Maurer, B., Swartz, L., \& Mainwaring, S. (2017). Social payments: Innovation, trust, Bitcoin, and the sharing economy. Theory, Culture \& Society. http://doi.org/10.1177/0263276417746466

Perry, M., \& Ferreira, J. (2018). Moneywork: Practices of use and social interaction around digital and analog money. ACM Transactions on Computer-Human Interaction, 24(6). http://doi.org/10.1145/3162082

Simmel, G. (2005). The philosophy of money. London and New York: Routledge. http://doi.org/10.4324/9780203481134

Wu, Z., \& Ma, X. (2017). Money as a social currency to manage group dynamics: Red packet gifting in chinese online communities. Proceedings of the $2017 \mathrm{CHI}$ 
Conference Extended Abstracts on Human Factors in Computing Systems - CHI EA '17, 2240-2247. http://doi.org/10.1145/3027063.3053153

Zelizer, V. A. (2017). The social meaning of money: Pin money, paychecks, poor relief, and other currencies (2.). Princeton University Press.

Zuboff, S. (2015). Big other: surveillance capitalism and the prospects of an information civilization. Journal of Information Technology, 30(1), 75-89.

http://doi.org/10.1057/jit.2015.5 